\title{
TAF6 wt Allele
}

National Cancer Institute

\section{Source}

National Cancer Institute. TAF6 wt Allele. NCI Thesaurus. Code C52608.

Human TAF6 wild-type allele is located in the vicinity of 10q24-q25.2 and is approximately $12 \mathrm{~kb}$ in length. This allele, which encodes transcription initiation factor TFIID subunit 6 protein, plays a role in the facilitation of transcription. 